\title{
Monitoring and Assessment of the Environmental Consequences and Risks of the Oil and Gas Field Development
}

\author{
Nataliya Yurkevich \\ IPGG SB RAS, 630090, Novosibirsk, Russia
}

doi: https://doi.org/10.21467/abstracts.93.100

\begin{abstract}
Environmental protection and maintaining the ecological balance are the most important state development priorities. The oil and gas industry of the Russian Federation is of key importance for the national economy, but it is one of the most environmentally disadvantaged and "opaque". Systemic crisis of the 1990s led to a decline in production in the oil and gas industry, attention to environmental protection and investment in development was minimized, and the priority of environmental problems dropped sharply [1].

The current stage of the country's economy development have a feature - the increasing role of the extractive industries, primarily the oil and gas complex. The expansion of the geography of oil and gas production in the direction of the northern and Far Eastern territories, the development of new territories (Eastern Siberia, the Arctic, and the Far East) determine increased requirements for the environmental component of the extraction, processing and transportation of raw materials. At the same time, comprehensive interdisciplinary studies of anthropogenic changes in natural ecosystems under the influence of oil and gas production are practically not carried out [2].

The aim of this work is to analyze the environmental problems of the oil and gas industry and to substantiate the relevance of environmental and economic modeling of processes that occur in the process of oil and gas production (using the objects of the oil and gas complex of the Yamalo-Nenets Autonomous District as an example).

The exploration and exploitation of oil and gas fields is accompanied by a range of environmental problems: gas emissions into the atmosphere during associated gas combustion, water intake, waste generation and disposal, contaminated water discharges to surface water bodies, oil spills, mechanical disturbances and chemical pollution of soils. The main share of air polluting substances is carbon monoxide (48\%), which is formed mainly due to the combustion of associated petroleum gas [1].According to the Federal State Statistics Service (www.gks.ru), the annual generation of waste from the extraction of fuel and energy minerals has more than doubled from 2005 to 2017.In 2017, the level of waste utilization at Oil and Gas Industry (OGI) amounted to 23\%, and in $2016-27 \%$, which indicates that despite the positive dynamics in waste disposal, the growth rate of their accumulation is much higher, therefore, in recent years there has been a decrease in the level of waste disposal in the OGI [3].The accumulation of waste in the OGI is due to the imperfection of production technologies, equipment wear and tear, as well as the poor resistance of landscapes to industrial impacts. With the intensification of subsoil development, manmade flows of matter dispersal are activated, which have a negative effect on the components of the environment. In recent years, the effects of oil and gas companies in environmentally sensitive northern territories have attracted particular attention.

A unique feature of the Yamal-Nenets Autonomous Okrug (Yamal-Nenets Autonomous Okrug) is the coexistence of two opposite areas of economic activity in a vulnerable and extreme Arctic environment: the development of rich reserves of mineral resources and traditional nature management of the indigenous peoples of the North. In recent years, the district has become a center of gas and oil production, intensive
\end{abstract}

(C) 2020 Copyright held by the author(s). Published by AIJR Publisher in "Abstracts of The Second Eurasian RISK-2020 Conference and Symposium” April 12- 19, 2020, Tbilisi, Georgia. Jointly organized by AMIR Technical Services LLC, Georgian Technical University, Institute of Geography (Kazakhstan) and Russian Institute of Petroleum Geology and Geophysics. 
The Second Eurasian RISK-2020 Conference and Symposium

industrial development of the territory has led to the formation of significant foci of pollution and environmental degradation [4].

The license area reaches 270 thousand $\mathrm{km}^{2}$, i.e. $37 \%$ of the territory of the Yamalo-Nenets Autonomous Okrug. Therefore, the level of anthropogenic impact during the development of mineral resources becomes decisive in the formation of the environmental situation throughout the district. The main directions of geoecological research in the territory of the Yamalo-Nenets Autonomous Okrug: the use of remote sensing methods for monitoring the Arctic territories, temperature monitoring of the permafrost zone, biogeochemical indicators of soil pollution, features of chemical pollution of soils in the area of oil and gas condensate fields, the influence of technogenic factors on surface waters in oil production areas, transformation of plant and soil cover, bottom sediments of rivers and lakes.

However, the issues of a comprehensive analysis of the geoecological and economic problems of the oil and gas industry in the Arctic, and the Yamalo-Nenets Autonomous Area in particular, are little studied and relevant. It should be noted that numerous geoecological studies of the effects of OGI on the components of the environment, carried out by different authors, are scattered, do not have general conclusions. In addition, data on the assessment of environmental damage and the cost of remediation measures are not provided, which is necessary for the development of scientific recommendations on environmental management in the region [1].

Thus, it is justified and relevant to use a comprehensive environmental and economic methodology for comparing environmental damage from the impact of oil and gas facilities on environmental components and reclamation costs. The authors collected a collection of soils, bottom sediments, water in the area of mothballed oil and gas wells, made an assessment of the state of the environment using a set of methods and taking into account the low cleaning ability of the Arctic ecosystems, made recommendations for further monitoring of the state of the environment in the area. We continue investigations on other mothballed deposits of the Yamalo-Nenets Autonomous Okrug to make decisions on the liquidation of facilities or the restoration of disturbed territories.

Funding: This research was funded by the BASIC RESEARCH PROJECT, project number 0266-20190008 .

\section{References}

[1] Yurkevich, N.V. and Filimonova, I.V., 2019. Analysis of ecological balance in the arctic regions of oil production on the example of YANAO. Interekspo Geo-Sibir', 2(5).

[2] Shvarts, E.A., Knizhnikov, A.Y., Pahalov, A.M., Sheresheva, M.Y. Ocenka ehkologicheskoj otvetstvennosti neftegazovyh kompanij, dejstvuyushchih v Rossii: rejtingovyj podhod // Vestnik Moskovskogo universiteta. - 2015. Seriya 6: Ekonomika (5). - P. 46-67.

[3] http://www.gks.ru/wps/wcm/connect/rosstat_main/rosstat/ru/statistics/environment/\#

[4] Kontorovich A.E., Suslov V.I., Brekhuncov A.M., Levinzon I.L., Korzhubaev A.G., Haritonova V.N., Churashev V.N. Strategiyasocial'no-ehkonomicheskogo razvitiyaYamalo-Neneckogo avtonomnogo okruga // Region: ehkonomika I sociologiya. - 2003. - № 3. - P. 3-38. 